\title{
LC-MS/MS analysis of neonicotinoid insecticides: Residue findings in chilean honeys
}

\author{
LC-MS/MS análises de inseticidas neonicotinoides: Resíduos \\ encontrados em méis chilenos
}

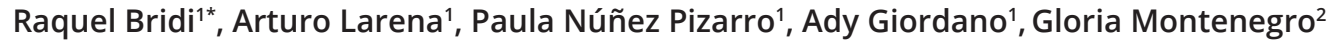 \\ 'Pontifícia Universidad Católica de Chile, Facultad de Química, Santiago, Chile \\ 2Pontifícia Universidad Católica de Chile, Facultad de Agronomía e Ingeniería Forestal, Santiago, Chile \\ *Corresponding author: rbridi@uc.cl \\ Received in August 2, 2017 and approved in October 17, 2017
}

\begin{abstract}
Neonicotinoids are a relatively new generation of insecticides that have been used for control of pests such as aphids, leafhoppers and whiteflies. This paper presents for the first time a determination of residues of four neonicotinoid insecticides (acetamiprid, thiamethoxam, thiacloprid and imidacloprid) in Chilean honey using QuEChERS extraction and UHPLC-MS/MS analysis. The limits of detection and quantification found for all analytes ranging from 0.34 to $1.43 \mu \mathrm{g} \mathrm{kg}^{-1}$ and from 0.30 to $4.76 \mathrm{\mu g} \mathrm{kg}^{-1}$, respectively. The extraction using QUEChERS method provided recoveries over $79 \%$ and the precision showed coefficient of variation lower than $20 \%$. These data are in agreement with the international criteria that recommend general recovery limits of $70-120 \%$. Of the 16 samples analyzed, in three honey samples neonicotinoids pesticides were detected. These three samples were collected from the same geographical area (Rengo). Fruit and grain production characterize the province of Rengo. The analysis of the botanical origin of these honeys showed the absence of pollen grains of crops and the majority presence of pollen grains of weeds such as Medicago sativa, Galega officinalis and Brassica rapa, which could be associated with crops. Although the residue levels found were low, the results also confirm the actual occurrence of a transfer of neonicotinoid insecticides from exposed honeybees into honey.
\end{abstract}

Index terms: QuEChERS; pesticide residues; food analysis.

\section{RESUMO}

Os neonicotinóides são uma geração relativamente nova de inseticidas que tem sido utilizado para o controle de pragas, como pulgões, cigarrinhas e moscas brancas. Este artigo apresenta pela primeira vez a determinação de resíduos de quatro inseticidas neonicotinóides (acetamiprida, tiametoxam, tiaclopride e imidaclopride) em méis chilenos empregando para extração o método QuEChERS seguido de UHPLC-MS/MS. Foram encontrados limites de deteç̧ão e quantificação aceitáveis para todos os analitos variando de 0,34 a 1,43 $\mu \mathrm{g} \mathrm{kg}$-1 e de 0,30 a $4,76 \mu \mathrm{kg}^{-1}$, respectivamente. A extração usando o método QuEChERS proporcionou uma recuperação maior que $79 \%$ e a precisão do método não excedeu um coeficiente de variação de $20 \%$. Esses dados estão de acordo com os critérios internacionais que recomendam limites gerais de recuperação de 70 -120\%. Das 16 amostras de mel analisadas foram detectados pesticidas neonicotinoides em três delas. Essas três amostras foram coletadas na mesma área geográfica (Rengo), a qual se caracteriza pela produção de grãos e frutas. A análise da origem botânica desses méis mostrou a ausência de grãos de pólen de espécies cultivadas nesta zona, porém mostrou uma presença majoritária de grãos de pólen de ervas daninhas, como Medicago sativa, Galega officinalis e Brassica rapa, as quais podem estar associadas a estes cultivos. Embora os níveis de resíduos neonicotinoides encontrados neste estudo são baixos, os resultados confirmam a ocorrência atual de uma transferência destes inseticidas ao mel das de abelhas expostas.

Termos para indexação: QuEChERS; resíduos de pesticidas; análise de alimentos.

\section{INTRODUCTION}

Neonicotinoid pesticides have become the most widely used class of insecticides worldwide, with largescale applications ranging from plant protection (crops, vegetables, fruits), veterinary products and biocides to invertebrate pest control in fish farming. Seven neonicotinoid compounds are available commercially worldwide: imidacloprid and thiacloprid (Bayer
CropScience), clothianidin (Bayer CropScience and Sumitomo), thiamethoxam (Syngenta), acetamiprid (Nippon Soda), nitenpyram (Sumitomo), and dinotefuran (Mitsui Chemicals) (Simon-Delso et al., 2015). Their use has increased considerably since the early 1990s and they represent one of the fastest growing types of insecticides put on the market since the launch of pyrethroids (Tanner; Czerwenka, 2011; Yáñez et al., 2013). The wide application of these insecticides is attributed to their selective mode of 
action at low doses, the ease and flexibility with which they can be applied, their long persistence, and their systemic nature (Aliouane et al., 2009; Blacquière et al., 2012; Bonmatin et al., 2015). However, various adverse effects on the environment have been reported, which occur via a number of routes including dust generated during riling of dressed seeds, contamination and accumulation in arable soils and soil water, run off into waterways, and uptake of pesticides by non-target plants through their roots or dust deposition on leaves. This provides multiple paths for chronic (and acute in some cases) exposure of nontarget animals. Neonicotinoids act in a very specific way as agonists on the postsynaptic nicotinic acetylcholine receptor of the insect's central nervous system, causing a blockage of signal transmission (Yáñez et al., 2013). Since the neonicotinoids block a specific neural pathway that is more abundant in insects than in warm-blooded animals, these insecticides are selectively more toxic to insects than mammals (Decourtye; Devillers, 2010; Jovanov et al., 2015). In humans, the effects of chronic neonicotinoid pesticide exposure on health are still little known (Cimino et al., 2017). Pollinators are exposed through direct contact with dust during drilling, consumption of pollen, nectar, or guttation drops from seed-treated crops and water (Bonmatin et al., 2015). Different studies have demonstrated that sub lethal amounts of neonicotinoids alone or combined with other pesticides, such as fungicides (Iwasa et al., 2004) may cause disorientation, reduced communication, impaired learning and memory, reduced longevity and disruption of honeybee brood cycles (Farooqui, 2013; Pisa et al., 2015). Furthermore, residues of these insecticides may be found in bee products such as honey, pollen, beeswax, and propolis (Jovanov et al., 2015; Kasiotis et al., 2014; Tanner; Czerwenka, 2011). For different neonicotinoids the maximum residue limit in honey has been set by the European Union (EU) to range from 10 to $200 \mu \mathrm{g} \mathrm{kg}^{-1}$. In this view, this paper presents for the first time a determination of residues of four neonicotinoid insecticides (acetamiprid, thiamethoxam, thiacloprid and imidacloprid) in Chilean honey using QuEChERS extraction and UHPLC-MS/MS analysis.

\section{MATERIAL AND METHODS}

\section{Chemicals and reagents}

Acetamiprid, thiamethoxam and thiacloprid were purchased from Sigma-Aldrich Laborchemikalien GmbH (Steinheim, Germany). Imidacloprid, Supel ${ }^{\mathrm{TM}}$ Que Citrate and Supel ${ }^{\mathrm{TM}}$ Que PSA/C18 were purchased from
Supelco (Bellefonte, PA, USA). Acetonitrile and methanol were HPLC grade and supplied by Merck (Darmstadt, Germany). Water was purified in a Milli-Q system (Synergy, Millipore ${ }^{\circledR}$, Darmstadt, Germany).

\section{Standards}

Individual standard stock solutions of $5 \mathrm{mg} \mathrm{mL}^{-1}$ for each analyte were prepared in acetonitrile and stored at $-80{ }^{\circ} \mathrm{C}$. The stock solutions were diluted and mixed with acetonitrile to obtain a mixture working solution of all investigated analytes of $0.1 \mathrm{mg} \mathrm{L}^{-1}$. A calibration curve was prepared by dilution in acetonitrile at concentrations between 0.5 to $45 \mu \mathrm{g} \mathrm{L}^{-1}$.

\section{Honey collection}

Sixteen honey samples proceeded from apiaries located in Malloa, Placilla, San Fernando, San Vicente, Rengo, Peralillo and Palmilla in the VI Region (Libertador Bernardo O'Higgins Region) of Chile were collected between 2013 and 2015. The botanical origin of the honeys was determined according to Chilean regulation (Montenegro et al., 2008). Ten grams of honey were diluted in $10 \mathrm{~mL}$ of distilled water, and centrifuged at 2,500 rpm for 5 minutes. The supernatant was eliminated and the sedimented pollen re-suspended in distilled water $(0.1 \mathrm{~mL})$. Five preparations from each honey sample were analyzed using optical microscopy and the pollen grains from each sample were identified using the palinoteque and reference bibliography.

\section{Matrix fortification}

The matrices used in this study were uncontaminated honeys collected from beehives unexposed to pesticide within an adequate perimeter. Five grams of each matrix was fortified with standards of the four studied neonicotinoids at $5,10,20,50$, and $100 \mu \mathrm{g} \mathrm{kg}^{-1}$ by adding the appropriate amount of the $10 \mathrm{mg} \mathrm{L}^{-1}$ analyte mixture working solution.

\section{QUEChERS type method}

Five grams of honey (blank or spiked with standard analyte solutions), $10 \mathrm{~mL}$ of water, and $10 \mathrm{~mL}$ of acetonitrile were mixed in a $50 \mathrm{~mL}$ centrifuge tube, which was then vigorously shaken by hand until a homogeneous solution was obtained. A mixture of Supel ${ }^{\mathrm{TM}}$ Que Citrate (Supelco) containing magnesium sulfate, sodium chloride, sodium citrate tribasic dihydrate, and sodium citrate dibasic sesquihydrate was added to the tube. The tube was shaken vigorously by hand for $1 \mathrm{~min}$ and centrifuged for $5 \mathrm{~min}$ at $3000 \mathrm{~g}$ and $10{ }^{\circ} \mathrm{C}$. An aliquot of $6 \mathrm{~mL}$ of 
the acetonitrile phase was transferred into a Pyrex tube containing Supel ${ }^{\mathrm{TM}}$ Que PSA/C18 (Supelco) containing magnesium sulfate, PSA and discovery $\mathrm{C} 18$. The tube was vigorously shaken by hand for $1 \mathrm{~min}$ and centrifuged for 5 min at $3000 \mathrm{~g}$ and $10^{\circ} \mathrm{C}$. Two milliliters of the supernatant was evaporated to dryness using a stream of nitrogen. The residue was redissolved in 1mL of methanol:water 20:80 (v/v) and subjected to LC-MS/MS analysis.

\section{UHPLC-MS/MS analysis}

Quantification was performed in a Triple Quad ${ }^{\mathrm{TM}}$ 4500 System coupled with an Eksigent Ekspert Ultra LC 100-XL system. Chromatographic separation was achieved in a Inersil ODS-4 column $(2.1 \times 100 \mathrm{~mm}, 3$ $\mu \mathrm{m}, \mathrm{GL}$ Sciences) at $40{ }^{\circ} \mathrm{C}$ with a mobile phase of $0,1 \%$ formic acid (A) and acentonitrile (B). Initial mobile phase concentration was $10 \% \mathrm{~B}$ increased to $80 \%$ in $3 \mathrm{~min}$, and kept constant for $8 \mathrm{~min}$ at a $0.4 \mathrm{~mL} / \mathrm{min}$ flow rate, with injection volume $10 \mu \mathrm{L}$. Electrospray ionization was performed in positive mode. Fragmentor voltage and collision energies were optimized for each analyte during infusion of the pure standard, and the most abundant fragment ion was chosen for the selected reaction monitoring. Quantitative analysis was carried out using multiple reaction monitoring (MRM) mode, using a first transition for quantification and a second transition for identification purpose. For the proposed method, the most intense characteristic MRM transitions were chosen for each analyte (Table 1).

\section{RESULTS AND DISCUSSION}

A melissopalinological assay was used to determine the botanical origin of the honeys samples selected for this study. In Chile, according the official policy (NCh2981.Of2005) established by the Standards Division of the National Institute for Standardization honey can be classified according to three types of botanical origins: monofloral, bifloral, or polyfloral (Montenegro et al., 2008). Monofloral honeys are those where at least $45 \%$ or more pollen grains found in it belong to the same species; bifloral honeys are those where pollens from two species are dominant within the total pollen grains, so that, as a whole, both species cover more than $50 \%$ of the total pollen grains, and there is not a difference higher than 5\% among them and; polyfloral honeys are those where no species reaches at least $45 \%$ of the total pollen grains, nor two of them covers more than $50 \%$ of the said total. In the analyzed honey we found nine monofloral, two bifloral and five polyfloral (Table 2). Samples from two native species were found Retanilla trinervia (tevo) and Quillaja saponaria (quillay) while the species introduced mainly found were Galega officinalis L. (galega), Brassica rapa (yuyo), Medicago sativa (alfafa) and Melilotus indicus.

According to previous data shown in the report of the Red de Acción en Plaguicidas y sus Alternativas de América latina (RAP-AL) the three most commonly used insecticides in this area (O'Higgins Region -Chile), are acetamiprid, thiamethoxam and imidacloprid (CIAP, 2012). In this study, four neonicotinoid insecticides were investigated (acetamiprid, thiacloprid, thiamethoxam and imidacloprid) in Chilean honey samples. The gradient system (formic acid $0.1 \%$ and acentonitrile) was applied to separate the four pesticides as independent peaks. Retention times $\left(t_{\mathrm{R}}\right)$ were determined individually and selected ion monitoring (SIM) of neonicotinoid insecticides with UHPLC-MS are presented in Table 1.

The linearity of the calibration curve of each pesticide was established by plotting UHPLC response area ratio versus concentration. The analytes showed linear behavior in the studied concentration range of 0.5 $-45 \mu \mathrm{g} \mathrm{L} \mathrm{L}^{-1}$. The correlation coefficient $\left(r^{2}\right)$ was found to be $\geq 0.994$ for all pesticides. Limit of quantification (LOQ) and limit of detection (LOD) were calculated for each insecticide and are presented in Table 3. A sample was considered positive when residue levels were above the LOQ.

Table 1: Retention times, molecular weight and monitored ions of neonicotinoid insecticides with LC-MS.

\begin{tabular}{ccccccc}
\hline Insecticide & $t_{\mathrm{R}}$ & Molecular mass & Quantification ion $(\mathrm{m} / \mathrm{z})$ & Identification ion $(\mathrm{m} / \mathrm{z})$ & $\mathrm{DP}^{\mathrm{a}}(\mathrm{V})$ & $\mathrm{CE}^{\mathrm{b}}(\mathrm{V})$ \\
\hline Acetamiprid & 4.89 & 222.7 & 126.0 & 89.9 & 86 & 86 \\
Thiamethoxam & 4.00 & 291.7 & 210.9 & 180.9 & 61 & 61 \\
Thiacloprid & 5.40 & 252.7 & 125.9 & 185.9 & 76 & 76 \\
Imidacloprid & 4.62 & 255.7 & 209.0 & 175.0 & 66 & 66 \\
\hline
\end{tabular}

a Declustering potential; ${ }^{b}$ Collision energy. 
Table 2: Floral composition of honey samples studied from VI Region, Chile.

\begin{tabular}{cccccc}
\hline & Apiaries localization & Types of botanical origins & Clasification & Predominant species & \% pollen grains \\
\hline 1 & Malloa & Monofloral & Native & Quillaja saponaria & 74.9 \\
2 & Placilla & Monofloral & Non- Native & Galega officinalis & 59.9 \\
3 & San Fernando & Monofloral & Native & Quillaja saponaria & 46.6 \\
4 & San Vicente & Monofloral & Native & Quillaja saponaria & 46.5 \\
5 & San Vicente & Monofloral & Native & Quillaja saponaria & 46.2 \\
6 & San Vicente & Polyfloral & Non- Native & Galega officinalis & 24.3 \\
7 & San Vicente & Polyfloral & Native & Retanilla trinervia & 32.6 \\
8 & San Vicente & Monofloral & Native & Quillaja saponaria & 46.2 \\
9 & Rengo & Bifloral & Non- Native & Galega/Medicago & 37.0 \\
10 & Rengo & Polifloral & Native & Luma apiculata & 34.8 \\
11 & Rengo & Bifloral & Non- Native & Galega/Medicago & 37.8 \\
12 & Peralillo & Monofloral & Non- Native & Galega officinalis & 54.0 \\
13 & Palmilla & Monofloral & Non- Native & Melilotus indicus & 50.3 \\
14 & San Vicente & Polyfloral & Non- Native & Melilotus indicus & 43.4 \\
15 & San Vicente & Polyfloral & Non- Native & Brassica rapa & 28.4 \\
16 & San Vicente & Monofloral & Native & Quillaja saponaria & 91.8 \\
\hline
\end{tabular}

Table 3: Limits of detection and quantification for four neonicotinoid insecticides in honey samples.

\begin{tabular}{clc}
\hline \multirow{2}{*}{ Insecticide } & \multicolumn{2}{c}{$\mu \mathrm{g} \mathrm{kg}^{-1}$ honey } \\
\cline { 2 - 3 } & $\mathrm{LOD}$ & $\mathrm{LOQ}$ \\
\hline Acetamiprid & 0.34 & 1.14 \\
Thiamethoxam & 0.11 & 0.30 \\
Thiacloprid & 1.43 & 4.76 \\
Imidacloprid & 0.47 & 1.56 \\
\hline
\end{tabular}

(LOQ) Limit of quantification; (LOD) limit of detection.

The QuEChERS methodology is composed of an extraction step with acetonitrile and partitioning using $\mathrm{MgSO}_{4}$, followed by dispersive solid phase extraction using primary-secondary amine (PSA). Different approaches have been used according anaytes and matrix. In honey samples, for neconictonoid determination, higher recoveries were obtained when adding citrate salts to the extraction methodology, that when using the original QuEChERS procedure with anhydrous magnesium sulfate and sodium chloride (Paradis et al., 2014). The extraction using this method for honey samples provided high recovery which ranged from $79 \%$ (acetamiprid) to $85 \%$ (thiamethoxan) for the fortification level of $20 \mu \mathrm{g} \mathrm{kg}^{-1}$ and from $99 \%$ (thiacloprid) to $101 \%$ (thiamethoxan) for the fortification level of $100 \mu \mathrm{g} \mathrm{kg}-1$ (Table 4); with coefficient of variation lower than $20 \%$. These data are in agreement with the criteria of document no. SANCO/12495/2011, that recommend general recovery limits of $70-120 \%$ (SANCO/12571/2013, 2013).

Table 4: Recovery rates for four neonicotinoid insecticides.

\begin{tabular}{cccc}
\hline \multirow{2}{*}{ Insecticide } & \multicolumn{3}{c}{ Recovery (\%) } \\
\cline { 2 - 4 } & $20 \mu \mathrm{g} / \mathrm{Kg}$ & $50 \mu \mathrm{g} / \mathrm{Kg}$ & $100 \mu \mathrm{g} / \mathrm{Kg}$ \\
\hline Acetamiprid & $79 \pm 1.4$ & $87 \pm 3.4$ & $100 \pm 2.4$ \\
Thiamethoxan & $82 \pm 3.6$ & $87 \pm 2.5$ & $100 \pm 2.5$ \\
Thiacloprid & $81 \pm 5.7$ & $84 \pm 3.3$ & $101 \pm 1.1$ \\
Imidacloprid & $85 \pm 0.3$ & $81 \pm 6.4$ & $99 \pm 4.0$ \\
\hline
\end{tabular}

The validated method was employed for the analysis of sixteen honey samples obtained from apiaries situated in different localities of VI Region, Chile and harvested in the summer months of the years 2013, 2014 and 2015. All honey samples were analyzed in triplicate. The main targets of the analyses were to examine the presence of neonicotinoid insecticide residues in Chilean honey. Figure 1 demonstrates the UHPLC-MS chromatogram of a honey sample containing 
neonicotinoid insecticides. The major peak at $5.40 \mathrm{~min}$ represents thiacloprid and the peak at 4.89 represents acetamiprid.

Table 5 shows the summary results of neonicotinoid residues detected in all samples that were analyzed in this study. Of the 16 samples analyzed, in one sample residues of all pesticides were detected, while in a second sample only acetamiprid, thiacloprid, and imidacloprid residues were found, and finally in a third sample only acetamiprid and thiacloprid residues were detected. The three samples with detected insecticide residues were collected from the same geographical area (Rengo, Chile). The province of Rengo is characterized by a high incidence of grain crops such as cereals, legumes, raps, sunflowers and beets, and fruit crops such as almonds, plums, pears, apples and grape. In addition to other provinces in the VI Region, Rengo makes up an important percentage of vineyard areas of the country. In the botanical origin of these honeys, the presence of pollen grains of these crops was not identified but was identified the majority presence of pollen grains of weeds that could be associated with these crops, such as Medicago sativa, Galega officinalis and Brassica rapa (Table 2).

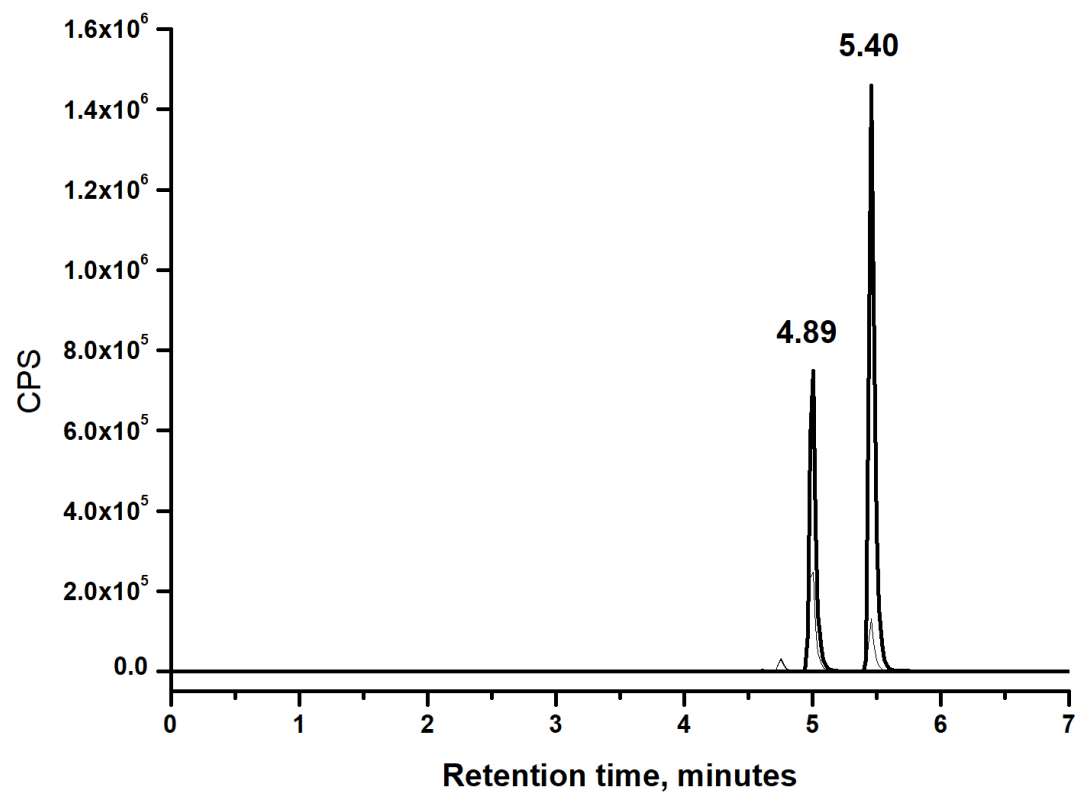

Figure 1: UHPLC-MS/MS chromatogram of a honey sample containing thiacloprid (peak at $5.40 \mathrm{~min}$ ) and acetamiprid (peak at $4.89 \mathrm{~min}$ ).

Table 5: Concentrations of neonicotinoid measured in honey samples from the VI Region of Chile.

\begin{tabular}{|c|c|c|c|c|}
\hline \multirow{2}{*}{ Sample } & \multicolumn{4}{|c|}{ Concentration $\mu \mathrm{g} \mathrm{kg}^{-1}$ honey } \\
\hline & Acetamiprid & Thiametoxan & Thiacloprid & Imidacloprid \\
\hline 1 & $n / d$ & $n / d$ & $n / d$ & $n / d$ \\
\hline 2 & $n / d$ & $n / d$ & $n / d$ & $n / d$ \\
\hline 3 & $\mathrm{n} / \mathrm{d}$ & $n / d$ & $\mathrm{n} / \mathrm{d}$ & $\mathrm{n} / \mathrm{d}$ \\
\hline 4 & $n / d$ & $n / d$ & $n / d$ & $n / d$ \\
\hline 5 & $\mathrm{n} / \mathrm{d}$ & $\mathrm{n} / \mathrm{d}$ & $\mathrm{n} / \mathrm{d}$ & $\mathrm{n} / \mathrm{d}$ \\
\hline 6 & $n / d$ & $n / d$ & $n / d$ & $n / d$ \\
\hline 7 & $\mathrm{n} / \mathrm{d}$ & $\mathrm{n} / \mathrm{d}$ & $\mathrm{n} / \mathrm{d}$ & $\mathrm{n} / \mathrm{d}$ \\
\hline
\end{tabular}


Table 5: Continuation...

\begin{tabular}{ccccc}
\hline \multirow{2}{*}{ Sample } & \multicolumn{4}{c}{ Concentration $\mu \mathrm{kg}^{-1}$ honey } \\
\cline { 2 - 5 } & Acetamiprid & Thiametoxan & Thiacloprid & Imidacloprid \\
\hline 8 & $\mathrm{n} / \mathrm{d}$ & $\mathrm{n} / \mathrm{d}$ & $\mathrm{n} / \mathrm{d}$ & $\mathrm{n} / \mathrm{d}$ \\
9 & 78 & $<\mathrm{LOQ}$ & 63 & 7 \\
10 & 34 & $\mathrm{n} / \mathrm{d}$ & 31 & $\mathrm{n} / \mathrm{d}$ \\
11 & 14 & $\mathrm{n} / \mathrm{d}$ & $<\mathrm{LOQ}$ & $<\mathrm{LOQ}$ \\
12 & $\mathrm{n} / \mathrm{d}$ & $\mathrm{n} / \mathrm{d}$ & $\mathrm{n} / \mathrm{d}$ \\
13 & $\mathrm{n} / \mathrm{d}$ & $\mathrm{n} / \mathrm{d}$ & $\mathrm{n} / \mathrm{d}$ & $\mathrm{n} / \mathrm{d}$ \\
14 & $\mathrm{n} / \mathrm{d}$ & $\mathrm{n} / \mathrm{d}$ & $\mathrm{n} / \mathrm{d}$ & $\mathrm{n} / \mathrm{d}$ \\
15 & $\mathrm{n} / \mathrm{d}$ & $\mathrm{n} / \mathrm{d}$ & $\mathrm{n} / \mathrm{d}$ & $\mathrm{n} / \mathrm{d}$ \\
16 & $\mathrm{n} / \mathrm{d}$ & $\mathrm{n} / \mathrm{d}$ & $\mathrm{n} / \mathrm{d}$ & $\mathrm{n} / \mathrm{d}$ \\
\hline
\end{tabular}

nd: non detected; < LOQ: residues of this pesticide above the LOD and below the limit of quantification.

\section{CONCLUSIONS}

In this work, an UHPLC-MS/MS analytical method based on QuEChERS sample pretreatment procedures was used for the determination of selected neonicotinoids in honey. Analysis of 16 honey samples from the VI Region of Chile showed the presence of neonicotinoid residues in three samples. These samples were collected from the province of Rengo. This province is characterized by grain and fruits crop, besides being an important vineyard area of the country. The analysis of the botanical origin of these honeys showed the absence of pollen grains of crops and the majority presence of pollen grains of weeds were such as Medicago sativa, Galega officinalis and Brassica rapa, which could be associated with crops controlled by the chemicals. Our study raises the concern of neonicotinoids residue in Chilean honey samples and the importance of regular analyses for the detection of residues of pesticides. Although neonicotinoids residue levels were low, they also confirm an actual occurrence of a transfer of neonicotinoid insecticides from exposed honeybees into honey.

\section{ACKNOWLEDGMENTS}

FIC (IDI 3034723-0) and FIC (IDI 30423322-0) supported this work.

\section{REFERENCES}

ALIOUANE, Y. et al. Subchronic exposure of honeybees to sublethal doses of pesticides: Effects on behavior. Environmental Toxicology and Chemistry, 28(1):113122, 2009.
BLACQUIÈRE, T. et al. Neonicotinoids in bees: A review on concentrations, side-effects and risk assessment. Ecotoxicology, 21(4):973-992, 2012.

BONMATIN, J. M. et al. Environmental fate and exposure; neonicotinoids and fipronil. Environmental Science and Pollution Research, 22(1):35-67, 2015.

CIAP. Disappearance of bees and pesticide residues in honey. Situation in the region of O'Higgins. Agrocompetitivo Boletin $\mathbf{n}^{\circ} \mathbf{1}$, Centro de Investigaciones Aplicadas - Universidad Federico Santa Maria. 2012. p.1-4.

CIMINO, A. M. et al. Effects of neonicotinoid pesticide exposure on human health: A systematic review. Environmental Health Perspectives, 125(2):155-162, 2017.

DECOURTYE, A.; DEVILLERS, J. Ecotoxicity of Neonicotinoid Insecticides to Bees. In: S. H. THANY. Insect Nicotinic Acetylcholine Receptors. Springer New York, New York, NY. p.85-95. 2010.

FAROOQUI, T. A potential link among biogenic aminesbased pesticides, learning and memory, and colony collapse disorder: A unique hypothesis. Neurochemistry International, 62(1):122-136, 2013.

IWASA, T. et al. Mechanism for the differential toxicity of neonicotinoid insecticides in the honey bee, Apis mellifera. Crop Protection, 23(5):371-378, 2004.

JOVANOV, P. et al. Development of HPLC-DAD method for determination of neonicotinoids in honey. Journal of Food Composition and Analysis, 40:106-113, 2015. 
KASIOTIS, K. M. et al. Pesticide residues in honeybees, honey and bee pollen by LC-MS/MS screening: Reported death incidents in honeybees. Science of The Total Environment, 485-486:633-642, 2014.

MONTENEGRO, G. et al. Aplicación de la Norma Chilena Oficial de denominación de origen botánico de la miel para la caracterización de la producción apícola. Ciencia e Investigación Agraria, 35:181-190, 2008.

PARADIS, D. et al. Sensitive analytical methods for 22 relevant insecticides of 3 chemical families in honey by GC-MS/MS and LC-MS/MS. Analytical and Bioanalytical Chemistry, 406(2): 621-633, 2014.

PISA, L. W. et al. Effects of neonicotinoids and fipronil on non-target invertebrates. Environmental Science and Pollution Research, 22(1):68-102, 2015.

SANCO/12571/2013. Guidance document on analytical quality control and validation procedures for pesticide residues analysis in food and feed. 2013. Available in: <https://ec.europa.eu/food/sites/food/files/plant/docs/ pesticides_mrl_guidelines_wrkdoc_11945.pdf>. Access in: October, 25, 2017.

SIMON-DELSO, N. et al. Systemic insecticides (neonicotinoids and fipronil): Trends, uses, mode of action and metabolites. Environmental Science and Pollution Research, 22(1):534, 2015.

TANNER, G.; CZERWENKA, C. LC-MS/MS analysis of neonicotinoid insecticides in honey: Methodology and residue findings in Austrian honeys. Journal of Agricultural and Food Chemistry, 59(23):12271-12277, 2011.

YÁÑEZ, K. P. et al. Determination of seven neonicotinoid insecticides in beeswax by liquid chromatography coupled to electrospray-mass spectrometry using a fused-core column. Journal of Chromatography A, 1285:110-117, 2013. 